REGARDS

SUR LEECONOMIE ALLEMANDE

BULLETIN ECONOMIQUE DU CRAC

\section{Regards sur l'économie allemande}

Bulletin économique du CIRAC

$100 \mid 2011$

Varia

\title{
Commerce : France et Allemagne restent soudées
}

\section{Isabelle Bourgeois}

\section{OpenEdition}

Journals

Édition électronique

URL : http://journals.openedition.org/rea/4232

DOI : $10.4000 /$ rea.4232

ISBN : 978-2-8218-0894-2

ISSN : 1965-0787

Éditeur

CIRAC

Édition imprimée

Date de publication : 17 mars 2011

Pagination : 54

ISSN : 1156-8992

Référence électronique

Isabelle Bourgeois, "Commerce: France et Allemagne restent soudées ", Regards sur l'économie allemande [En ligne], 100 | mars 2011, mis en ligne le 19 septembre 2011, consulté le 15 septembre 2020. URL : http://journals.openedition.org/rea/4232

Ce document a été généré automatiquement le 15 septembre 2020

(C) CIRAC 


\title{
Commerce : France et Allemagne restent soudées
}

\author{
Isabelle Bourgeois
}

En 2010, la France était, comme toujours depuis 1961, le client numéro un de la RFA qui y avait exporté des biens d'une valeur de 90,7 milliards $€(+11,5 \%$ par rapport à 2009), soit 9,5\% du total de l'export allemand (959,5 milliards $€$ ). Les Etats-Unis et les Pays-Bas étaient numéro deux et trois avec respectivement 65,6 milliards $€(+20,6 \%)$ et 63,2 milliards $€(+18,9 \%)$ d'exportations (respectivement $6,8 \%$ et $6,6 \%$ du total). La France était le $3^{\mathrm{e}}$ fournisseur de l'Allemagne $(61,8$ milliards $€ ;+15,8 \%)$, avec une part de $7,7 \%$ du total des importations (806,2 milliards $€$ ). En tête venaient la chine et les Pays-Bas, avec une part respective de $9,5 \%$ et $8,5 \%$ et une valeur de 76,5 et 68,8 milliards $€$ (soit $+35,0 \%$ et $+23,7 \%$; Destatis, 08-03-11).

\section{INDEX}

Mots-clés : commerce extérieur, conjoncture, exportation, importation, relations économiques extérieures, relations franco-allemandes 